УДК 667.633 .2

ББК Н36я73

\title{
PROSPECTIVE PRODUCTION WAYS OF NEW HEAT-RESISTING MATERIALS BASED ON POLYIMIDES
}

\author{
Krutsko Elvira Tikhonovna \\ Doctor of Technical Sciences, Professor, \\ Department of Technology of Petrochemical Synthesis and Polymer Materials Processing, \\ Belarusian State Technological University \\ prok_nr@mail.by \\ Sverdlova St., 13a, 220006 Minsk, Belarus
}

\section{Prokopchuk Nikolay Romanovich}

Doctor of Chemical Sciences, Professor, Head of the Department of Technology of Petrochemical Synthesis and Polymer Materials Processing, Belarusian State Technological University, Corresponding Member of National Academy of Sciences of Belarus prok_nr@mail.by Sverdlova St., 13a, 220006 Minsk, Belarus

\footnotetext{
Abstract. The article is devoted to production and study of materials based on different kinds of industrially manufactured polyimides, including chemical modification of reactivity of multifunctional compounds. The presence of reactive carboxyl, amide and amino groups, capable to interact with multifunctional monomeric and oligomeric modifiers, in macromolecules of polyamide acids, gives the chance of receiving the polyimide materials possessing properties of polymers. As a result, we observe improvement of strength properties and thermal characteristics of new polymeric materials for practical aims.

Key words: polyimide, geometrical parameters, structural characteristics, properties, modification, block copolyimides.

Introduction. Entire prehistory of heatresistant polymer investigations led to the belief that the most successful structure can be considered a rigid structure consisting of a benzene ring firmly connected to two fivemembered nitrogen-containing rings. Polymers of this kind have one common name of aromatic polyimides (PI).

For the past 60 years the polymers of this class are the most commonly used heat-

resistant polymers due to the complex of unique characteristics. They firmly hold the primacy among the materials being a source of a huge range of products for all branches of science and technology. The production of the tapes, fibers, coatings, paints, plastics, membranes, composites, bonding, foamed and other materials is based on polyimides. Each of them can work in extremely high thermic conditions $[2 ; 4 ; 11 ; 16 ; 23]$.
} 
Main part. Polyimide films were the first commercial material used to create highly heat insulators. Currently polyimide films release in the world is at a level of more than 1000 tons per year. They are used as insulators of such electrical items as cables, generators, motors and other components and assembly parts used at elevated temperatures [5;9].

High stability of the surface layers of polyimide films determines their preferential use for the manufacture of resistors. Variation on the surface resistance of polyimide films is 3 times lower than that of pyroceramic substrates.

Polyimide films are used in the manufacture of heating elements of devices, heat-resistant coatings, printing plates, wires and cables. Protective film with adhesive coating protects conductive pattern of flexible printed circuits against corrosion preventing short circuits and accidental conductors from contact with metal surfaces of the equipment.

It should be noted that the need for film coatings in the microelectronics has dramatically increased in recent years. The special emphasis is given to the using of ultrathin films with low dielectric constant.

Some of the polyimide films are optically transparent in the visible and ultraviolet regions of the spectrum. It allows their using in optical communications technology.

Polyimides are used in the manufacture of elongate fiber optics and microfilters. A number of polyimide films and film coatings is used in various systems of liquid crystal displays.

Metallized polyimide films are of great importance in wireless communication systems as well as in the production of various resistors and capacitors. Their scope goes beyond electricity designs, and especially where it is necessary to use a durable, flexible and heat-resistant substrate for mirrors, screens and reflectors for energy flows of wide range. The polyimide film may be combined with a metal foil with an adhesive or a metal is sprayed directly onto the film surface. In some cases the metal is introduced into the polyimide film at the stage of prepolymer. For example, certain amounts of gold or silver, are introduced as a fine dispersion in a solution of a polyamic acid. The film with a homogeneous distribution of the metal throughout the whole product volume is obtained after its imidization and its surface treatment $[18 ; 20]$.
As for the surface metallization, the polyimide films are used in space technology, mirrored surfaces of solar panels and components of solar technological equipment, as well as the fabrication of multilayer protective fabrics for suits of astronauts, firefighters and emergency crews at hot shops and nuclear power plants.

Particular attention is being given to exploitation of ultrathin films of Langmuir Blodgett (LB). Polyimide LB films are widely used in the construction of three-layer photodiodes, photolithographic purposes, in the process of stabilization of alternating voltage switching systems in the memory. It should be noted that the soluble polyimides are required as the photosensitive elements of both negative and positive types. This trend of the polyimide materials is considered to be one of the priorities.

Nor can we fail to dwell on the polyimide fibers.

During the intensive search of new heatresistant fiber-forming polymers in the former Soviet Union the greatest scientists in the field of polymer chemistry Academician V.V. Korshak, RAS Corresponding Member M.M. Coton, A.N. Pravednikovym and many others laid the theoretical basis for the creation of polyimide fibers which have been successfully implemented in industrial scale. Until now the heat-resistant fiber Arimid $\mathrm{T}$ remains the most heat-resistant synthetic fiber. The range of its working efficiency is from $-27{ }^{\circ} \mathrm{C}$ till $+450{ }^{\circ} \mathrm{C}$. These fibers are nonflammable; retain elasticity and strength characteristics at liquid nitrogen temperature to the full extent. They are the only fibers that can withstand integrated doses of nuclear and ultraviolet irradiation to $3000 \mathrm{Mrad}$ without significant change of operational properties. For polyimide fibers and fabrics almost complete recovery of the elastic deformation is characterized at elevated temperatures.

The combination of the unique properties of PI fibers allows their use for equipment operating for long periods at elevated levels of radiation and temperature; for the reinforcement of rubber products, GRP laminated structural materials; for the manufacture of uniforms for workers in the area of high radiation activity and high temperatures; for creation of space filters for cleaning of hot gases and corrosive liquids. Fibers obtained from optical fibers for fiber optics $[12-14 ; 15 ; 23]$. 
Belarus has being taken part in many polyimides synthesis research, fibers and films derivation, study of their properties $[3 ; 6-8 ; 10$; $23 ; 25]$. Research results were a prerequisite for the development of new materials in microelectronics and their introduction into the production technology of large and very large scale integrated circuits at PD "Integral" with a significant economic effect.

The polyimide foam manufacture is one of the priorities in the development of advanced materials. The unique qualities of polyimides have attracted attention of developers to create foam protective structures for high-speed vehicles, primarily for aircraft and spacecraft. The challenge of the protection of ship's crew as well as scientific equipment at unmanned flight was developed long before the implementation of flight at speeds of the order of tens of thousands of kilometers per hour. The increased heat and flame resistance, low density of inner cladding cabins, flexibility and resilience of the various elements of isolation and the use of multi-layer insulation in the seamless stitching of individual components are the main protection requirements. The foam insulation should not burn, give off toxic products of thermal degradation of the polymer and smoke in extreme emergency situations. The polyimides are the most suitable polymers meeting these requirements. The various technological methods have been developed for their manufacture. The specific product characteristics of polyimide foams may have a wide range of different properties (density, thermal, acoustic and fire- resistance, mechanical and material yield strength, environmental friendliness). The polyimide foams are used in the production of insulation panels for covering booths of supersonic aircraft and manned spacecraft.

In unmanned aerial vehicles (satellites) thermal mode of polymer operation provides the range from -60 to $+180^{\circ} \mathrm{C}$, the mechanical load is 3 times larger than the overload valid at start of manned spacecraft, and background radiation depends on the specific conditions of the satellite. The polyimide foams protection provides continuous television and radio communication, reliable storage of scientific information and coordinated work of all electrical, electronic and optical equipment of space laboratories.

Nowadays there are real predictions to create large structures of high strength and minimum weight by using reinforced hollow carbon fibers connected with ultrathin semiconductor hybrid polyimide films in space. These solutions allow you to create solar panels of huge capacity to serve the different spacecraft.

The polyimide foams are widely used in microelectronics as dielectrics with a very low dielectric constant, protective sensor coatings, stress buffers to compensate vibration load of many components of integrated circuits in extreme situations.

However, some additional problems required the further material's improvement, arise in spite of the achievement of the basic parameters of suitability of these materials to meet the stringent requirements. The chemical modification of polyimides is one way of solving this problem.

Outstanding properties of polyimides allowed in recent years to create and implement a new generation of membranes which are used for the separation of gases, vapors and liquids. Polyimide membranes differ with extremely high resistance to almost all chemical agents. Their thermal stability allows to realize separation processes for a long period of time at high temperatures. The high selectivity is indispensable for gas separation. The ability to obtain highly selective and at the same time permeable to water and organic substances membranes is explained by special membrane molecular design of polyimides.

The implementation of this problem is possible on the macromolecular level when the methods of structures synthesis with well- articulated rigid portions of the polymer backbone which create a calibrated interchain packing with a very narrow distribution of free volume has been developed.

Fundamental theoretical development and extensive experience with numerous practical synthesis of polyimides polycondensation techniques [12-14; 19] allowed to use in practice more than one hundred polyimides with diverse chemical structure to create membranes of diverse functionality. Polyimide membranes show the highest effect in the process of the separation and purification of gas mixtures (particularly with "simple gases" such as hydrogen, helium, carbon dioxide and some other petrochemical production gases).

Recent research in polyimide membrane showed that because of their high chemical inertness and stability they are promising even in the medical industry for creating artificial organs e.g. the membranes of fluorinated polyimides are 
tested in the apparatus of artificial light. This material for vascular oxygenation compared with silicone coatings shows a 4-fold improvement in oxygen and carbon dioxide gas exchange and the good compatibility with blood elements.

Currently, polyimide membranes industry leaders are Japan and the United States.

Nowadays, up to 500 various composite materials and products of multiple types based on polyimide plastics are annually patented. The contained polyimides and their derivatives ranges from 5 to $100 \%$.

For example, strong and heat-resistant composite materials with operating temperatures up to $500{ }^{\circ} \mathrm{C}$ have been created. Such composite imidoplastics are used in aerospace industry products (i.e. tips for nose cones and leading edges of the wings of supersonic aircraft, gas rudders, nozzle liners, flue missile components and aircraft engines).

A brand AURUM polyimide has been developed in Japan. It has been assigned to the category of high performance plastics. It is stable with no weight loss up to $500{ }^{\circ} \mathrm{C}$, resistant to radiation and inert to nearly all reactants. Main applications of the polyimide composite material are structural elements and slip components.

The imidoplastics with carbon fillers are competitive in the manufacture of components and mechanisms in automotive engineering. They can be used as substitutes for aluminum and titanium alloys at high speeds, temperatures and loads, energy insulation for nuclear reactors [20].

The polyimide varnishes are successfully used for enameled wire of copper, aluminum, steel.

With regard to recent developments the emergence of new problems is associated with microelectronics [23]. This is explained by the fact that this area now requires highly soluble polyimide materials with hue, flexibility, high transparency of coatings, high adhesive characteristics of the sprayed metals layers, low shrinkage.

The research in the synthesis, the relationship of the chemical structure, the structure and performance of new properties developed at the Department of THC and MRP film-forming polyimide compositions in order to obtain on their base some functional materials of different assignment for the microelectronics industry were dedicated to resolve these complex problems [17].

Three PhD (candidate) and one doctoral dissertation theses on this topic were defended at
BSTU. More than 20 patents of the Republic of Belarus were received; more than 50 articles in scientific journals were published. The monograph has been published. A group of authors was awarded by the National Academy of Sciences of Belarus for the series of papers "Polyimides. Synthesis. Properties. Application".

It should be noted that polyimides synthesis requires a good theoretical training, highly qualified specialists in the field of the experimental chemistry to carry out fundamental research that should precede the successful solution of specific practical problems.

The following achievements could be marked as an example of the new materials creation based on serially produced polypyromellitimides at the Department of THC and MRP of BSTU during last five years:

1. A new composite film material with improved strength and adhesion properties to a layer of such deposited metals as aluminum and copper was proposed on the basis of a detailed researches of UV, IR, EPR of laws spectroscopy of prepolymer polyimide complexation with metal-containing modifying components (ferrocenium hexafluorophosphate and cobalt acetylacetonate) $[3 ; 6 ; 8]$.

2. A solution of creation of soluble polyimide systems by synthesizing fragmented polypyromellitimides with bulky and curved portions of the polymer chains reducing intermolecular interactions and their subsequent chemical cyclodehydration leading to the solubility of macromolecules was proposed to enable the application of polyimides in gallium and arsenide technology of microelectronic devices [25].

3 . The calculations of geometrical parameters of polyimide macromolecules fragments were performed to explain the solubility reasons of bloksopolyimides. It was shown that such a structure of the polymer molecules consists of strongly folded conformation with high conformational parameter. It provides a more open structure of the polymer and facilitates its dissolution $[7 ; 10]$.

4. Variety of requirements for the properties of polyimide materials is often achieved by using complex modifiers. This approach have been used to manufacture the low-shrinkage polyimide compositions for potting compounds and protective layers by co-administration of aerosil 
prepolymer, gadolinium oxide and crosslinking agent - bysmaleimide.

Conclusion. The manufactured polyimide film-forming materials have successfully passed the pilot-scale test at OJSC "Integral" and can be used in modern microelectronics .

Currently the department of the TNC and MRP at BSTU as well as BSU and BSUIR continue their researches in the field of polyimides.

\section{REFERENCES}

1. Baron A.A., Gevlich D.S., Bakhracheva Yu.S. Specific Plastic Strain Energy as a Measure of the Cracking Resistance of Structural Materials. Russian metallurgy, 2002, no. 6, pp. 587-592.

2. Bessonov M.I. et al. Poliimidy - klass termostoykikh polimerov [Polyimides is a Class of Heat-Resistant Polymers]. Leningrad, Nauka Publ., $1983.328 \mathrm{p}$.

3. Bogushevich S.E., Globa A.I., Krutko E.T. Metalcontaining Polyimides. Polyimides \& High Performance Polymers. Montpellier, 2008, pp. 291-300.

4. Buller K.U. Teplo- $i$ termostoykie polimery [Heat- and Heat-Resistant Polymers]. Moscow, Khimiya Publ., 1984. 1056 p.

5. Feng K. et al. Synthesis and Properties of Novel Photosensitive Polyimides Containing Chalcone Moiety in the Main Chain. Journal of Polymer Science. Part A: Polymer Chemistry, 1998, vol. 36, no. 5, pp. 685-693.

6.Globa A.I. et al. Electrorheological Fluids Based on the Modified Aromatic Polyimides. Electrorheological Fluids and Magnetorheological Suspensions: Abstracts of 11th International Conference, Dresden, September 12-16, 2008. Dresden, 2009. $18 \mathrm{p}$.

7. Globa A.I., Krutko E.T. et al. Patent 11322 RB "Poliimidnaya kompozitsiya dlya zashchity kristallov poluprovodnikovykh $i$ integralnykh skhem" [Patent 11322 RB "Polyimide Composition for Protection the Crystals of Semiconductor and Integrated Circuits"]. Afitsyyny bulletin, 2008, no. 6, pp. 11-17.

8. Karabko A. et al. Electrorheological Fluids Based on the Modified Aromatic Polyimides. Journal of Physics Conference Series, 2009, vol. 148, pp. 48-53.

9. Koton M.M. Rol aromaticheskikh poliimidov v sovremennoy nauke i tekhnike [The Role of Aromatic Polyimides in Modern Science and Technology]. Prikladnaya khimiya, 1995, vol. 68, no. 5, pp. 882-826.

10. Krutko E.T., Globa A.I. et al. Rastvorimye blok-sopoliimidy [Soluble Block Copolyimides]. Doklady Natsionalnoy akademii nauk Belarusi [Reports of the National Academy of Sciences of Belarus], 2011, vol. 55, no. 3, pp. 79-82.
11. Krutko E.T. et al. Poliimidy. Sintez. Svoystva. Primenenie [Polyimides. Synthesis, Properties, Application]. Minsk, BGTU Publ., 2002. 304 p.

12. Kudaykulova S.K. et al. Reflecting Conductive Polyimide Films Prepared by Chemical Plating. Lyakishev N.P. et al., eds. Proceedings of the $17^{\text {th }}$ Mendeleev Congress on General and Applied Chemistry, Kazan, 21-26 September. Kazan, 2003, vol. 3, p. 224.

13. Kuznetsov A.A. Sintez poliimidov $v$ rasplave benzoynoy kisloty. Avtoref. dis. ... d-ra khim. nauk [Synthesis of Polyimides in the Melt of Benzoic Acid. Dr. chem. sci. abs. dis.]. Moscow, 2008. 42 p.

14. Kuznetsov A.A., Tsegelskaya A.Yu, Buzin P.V. Odnostadiynyy vysokotemperaturnyy sintez poliimidov $\mathrm{v}$ rasplave $\mathrm{v}$ benzoynoy kislote: kinetika reaktsiy, modeliruyushchikh stadii polikondensatsii i tsiklizatsii [One-Stage High-Temperature Synthesis of Polyimides in the Melt of Benzoic Acid: Kinetics of Reactions Modelling the Stages of Polycondensation and Cyclization]. Vysokomolekulyarnye soedineniya, 2007, vol. 49, no. 11, pp. 1895-1904.

15. Meleshko T.K. et al. Elektroprovodyashchie plenkoobrazuyushchie kompozitsii na osnove smesi polianilina i poliimidov [Conductive Film-Forming Compositions Based on a Mixture of Polyaniline and Polyimides]. Vysokomolekulyarnye soedineniya, 2009, vol. 51, no. 3, pp. 447-453.

16. Mikhaylin Yu.A. Termoustoychivye polimery i polimernye materialy [Heat-Resistant Polymers and Polymeric Materials]. Saint Petersburg, Profession Publ., 2006. 623 p.

17. Prokopchuk N.R. Korrelyatsiya konfiguratsiy tsepey, makromolekulyarnoy struktury i termomekhanicheskikh svoystv orientirovannykh poliarilenimidov. Dis. ... kand. fiz.-mat. nauk [The Correlation of Configurations of Circuits, Macromolecular Structure and Thermomechanical Properties of Oriented Polyarilenimids. Cand. phys. and math. sci. diss.]. Leningrad, 1977. $160 \mathrm{p}$.

18. Rusanov A.L. et al. Novye ftorosoderzhashchie poliimidy [New Fluorine-Containing Polyimides]. Vysokomolekulyarnye soedineniya, 2006, vol. 48, no. 8, pp. 1527-1530.

19. Rusanov A.L. et al. Novye karboksilsoderzhashchie poliimidy [New Carboxyl-Containing Polyimides]. Vysokomolekulyarnye soedineniya, 2006, vol. 47, no. 5, pp. 859-863.

20. Sazanov N. Applied Value of Polyimide. Journal of Applied Chemistry, 2001, vol. 74, no. 8, pp. 1217-1233.

21. Semenova L.M., Bakhracheva Yu.S., Semenov S.V. Laws of Formation of Diffusion Layers and Solution of the Diffusion Problem in TemperatureCycle Carbonitriding of Steel. Metal Science and Heat Treatment, 2013, vol. 55, no. 1-2, pp. 34-37. 
22. Shapochkin V.I., Semenova L.M., Bakhracheva Yu.S., Gyulikhandanov E.L., Semenov S.V. Effect of Nitrogen Content on the Structure and Properties of Nitrocarburized Steel. Metal Science and Heat Treatment, 2011, vol. 52, no. 910, pp. 413-419.

23. Yakimtsova L.B. Sintez plenkoobrazuyushchikh aromaticheskikh poliimidov setchatogo stroeniya. Avtoref. dis. ... kand. khim. nauk [The Synthesis of Film-Forming Aromatic Polyimides of Reticular
Structure. Cand. Chem. Sci. Abs. Diss.]. Minsk, $1997.17 \mathrm{p}$.

24. Yi M.H. et al. Synthesis and Characterization of Soluble Polyimides from 1,1'-bis (4-aminophenyl)Cyclohexane Derivatives. Macromolecules, 1997, vol. 30, no. 2, pp. 5606-5611.

25. Zhdanuk E.N., Globa A.I., Krutko E.T. Thermal Imidization of Polyimide Compositions. E-MRS: abstracts of European Materials Research Society, Warsaw, 1418 September 2009. Warsaw, 2009, pp. 215-216.

\title{
ПЕРСПЕКТИВНЫЕ СПОСОБЫ ПРОИЗВОДСТВА НОВЫХ ТЕРМОСТОЙКИХ МАТЕРИАЛОВ НА ОСНОВЕ ПОЛИИМИДОВ
}

\author{
Круцко Эльвира Тихоновна
}

Доктор технических наук, профессор кафедры технологии нефтехимического синтеза и переработки полимерных материалов Белорусского государственного технологического университета prok_nr@mail.by ул. Свердлова, 13a, 220006 г. Минск, Беларусь

\section{Прокопчук Николай Романович}

Доктор химических наук, профессор,

заведующий кафедрой технологии нефтехимического синтеза и переработки полимерных материалов Белорусского государственного технологического университета, член-корреспондент Национальной академии наук Беларуси prok_nr@mail.by ул. Свердлова, 13a, 220006 г. Минск, Беларусь

Аннотация. Статья посвящена производству и исследованию материалов на основе различных видов полиимидов, полученных в ходе промышленного производства, в том числе в результате химической модификации активности многофункциональных составляющих. Наличие в макромолекулах полиамидных кислот химически активного карбоксила, амида и аминогрупп, способных к взаимодействию с многофункциональными мономерными и олигомерными модификаторами, дает возможность получить полиимидные материалы, обладающие свойствами полимеров. В результате происходит увеличение прочности и улучшение термальных характеристик новых полимерных материалов для практических целей.

Ключевые слова: полиимид, геометрические параметры, структурные характеристики, свойства, модификация, блоки-сополиимиды. 